Georgetown University Law Center

Scholarship @ GEORGETOWN LAW

1973

\title{
Alternative Schools: Better Guardians than Family or State?
}

Judith C. Areen

Georgetown University Law Center, areen@law.georgetown.edu

This paper can be downloaded free of charge from:

https://scholarship.law.georgetown.edu/facpub/1533

Judith C. Areen, Alternative Schools: Better Guardians than Family or State?, 81 SCH. REV. 175 (1973)

This open-access article is brought to you by the Georgetown Law Library. Posted with permission of the author. Follow this and additional works at: https://scholarship.law.georgetown.edu/facpub

Part of the Educational Methods Commons 


\title{
Alternative Schools: Better Guardians
}

\section{than Family or State?}

\author{
J U D I T H C. A R E E N
}

Georgetown University Law Center

Alternative schools have become increasingly popular in this country in the last few years, at least as measured by the amount of attention focused on them by magazines and TV networks. A whole new genre of books has emerged, too, beginning with Paul Goodman's Compulsory Mis-Education and followed by the Kozol-Holt-Herndon series on the failings of most public schools. A. S. Neil's Summerhill and Maria Montessori were rediscovered; Jay Featherstone publicized the British Infant School model; and George Dennison described his experiences with a new school for poor inner-city children.

Alternative schools began appearing as well, growing in the last five years from perhaps twenty-five to over 600. Over 200 were founded in the past year alone, ${ }^{1}$ and these statistics do not reflect the growing number of public schools which have been remodeled drastically enough to deserve the label "alternative schools."

This is not to suggest that demands for alternatives to public schools are new. Rather, there have been strong clashes between families and the state over how to educate children since 
schooling was first made compulsory in the nineteenth century. The issues involved varied as much as families do in their notions of what values or skills to teach or of how to teach. The state, by contract, was fairly consistent in its position of using the public schools to further the melting pot. One language was encouraged as was the development of a uniform curriculum which would teach all children what they would need to know to become responsible citizens.

The biggest fight initially was over the role of religion. Should religious values be taught in publicly funded schools? If so, from which viewpoint? Because this second question was so difficult to answer in our religiously pluralistic society with its tradition of resistance to state-imposed religion, the state adopted a hands-off policy. It did not forbid religious schools, but it would not encourage them by supplying state funds. The number of privately funded church-related schools grew nonetheless, so that today most nonpublic alternative schools are church related. ${ }^{2}$

Now even that religious compromise is challenged. While some parents still want the opportunity to choose churchrelated schools, they also want them to provide the same scope and quality of secular instruction as public schools. These demands, translated into requests for more courses or smaller classes, have forced church-related schools to hire more lay teachers - who cost more than teaching clergy. The clergy, too, want more pay for their labor. Costs in churchrelated schools have thus spiraled to the point where it is becoming impossible to provide the quality demanded at a price parents can or will pay.

\section{Challenges to Public Schools}

But the significant change in the challenge to the public school system is not the new urgency of financial demands from church-related schools. It is the increasing number of

Judith C. Areen is associate professor of law, Georgetown Law Center, and is the former director of the Education Voucher Study of the Center for the Study of Public Policy in Cambridge. 
parents who are dissatisfied with public schools not for religious but for pedagogic, cultural, or political reasons. Black parents are demanding schools that teach black history and culture. Many want schools that will teach their children as successfully as white children are taught. They want better reading and math scores today and equal job success tomorrow. White parents are also complaining about course content. Some parents of all races want schools to focus more on personal development and fulfillment and less on preparing children just to fit into the present job structure. Others argue about the amount of discipline exercised. Some want a greater racial or socioeconomic mix of students in their schools; others, a smaller one.

These diverse complaints appear to have a common thread that may be the real concern of most parents: individual public schools are too insulated from the families they serve. It is ironic that in a nation officially opposed to the evils of monopoly, particularly in the insidious guise of socialism, we have an education system that offers no choice to most parents. Imagine the protest if we were allowed to see only one channel of free TV, a channel operated by the government. Yet, we blithely require most children to spend over ten of their most formative years in one government-operated school.

In theory, the monopoly structure should not matter where parents can exercise some control over the school, by vote when the next school board member is up for reelection, or by lobbying for statutory changes in the state legislature. But in fact such control seems sadly inadequate when compared to the pervasive role the school plays in the lives of most children. Parent control is almost lacking where school boards are appointed. The monopoly structure has not been widely challenged since it is by definition established to respond to the preferences of the local majority. They select the majority of the school board, who then impose the style of schooling favored by the majority of all schools in the district. Only those who differ from majority preferences in some fashion are forced to go to a school not to their liking (unless they are wealthy enough to move to a different district or to afford a private school). 
Traditionally most alternative school supporters have looked outside public school systems for change. Consequently their biggest problem usually is obtaining enough money to operate. But to the extent that parents' objections to public schools are the result of the structure of public school systems, it may turn out to be more feasible to make public schools "private" than to make private schools "public." 3

Currently, many educators who object to providing vouchers or tax credits to enable parents to select "private" alternative schools at the same time agree to the merits of parental options within the public system. ${ }^{4}$ Either approach, of course, will require fairly drastic changes in the way schools are funded and students and schools paired, and for the most part they are changes that no one person or group has the authority to make. On the other hand, a variety of decision makers, ranging from the local school administrators, the school board, the city council, state education officials, the state legislature, to the governor, can effectively veto such changes. School boards, for example, do not have the authority in most cases to provide public money to private alternative schools even if they wish. In many states a constitutional amendment would be required $;{ }^{5}$ in most others a special bill would have to be passed by the state legislature to enable even one district to provide public funds to even one such alternative school.

\section{Prospects for Legislative Support}

Prospects for such legislative action are dim at present, primarily because there is not a sizable constituency committed to supporting aid to secular alternative schools. On the other hand, there is a large group of parents supporting aid to church-related schools who have been very successful recently in getting aid bills enacted. Significantly, both major party candidates this year endorsed the concept of aid to church-related schools. The aid bills passed to date, however, do not proffer much help for secular alternative schools. The amounts appropriated average less than $\$ 200$ a student, which is of little use to alternative schools which have neither a religious sponsor nor rich patrons to foot the rest of the bill. 
Interestingly, the Supreme Court has kept the way open for broader financial support to alternative schools by striking down all legislation reviewed to date on the grounds that it violates the constitutional wall between church and state.

In Lemon v. Kurtzman, the Supreme Court declared unconstitutional two state programs that reimbursed nonpublic schools for certain instructional costs. ${ }^{6}$ The Pennsylvania program had attempted to avoid church-state prohibitions by limiting reimbursement to instruction in courses legislatively defined as "secular": mathematics, physical education, physical (but not biological) sciences, and modern (but not ancient) languages. The Rhode Island program made a similar attempt by limiting reimbursement to the salaries of "secular" teachers, who were defined as those who (1) taught "secular" subjects and (2) signed a pledge that they did not teach religion. The Court, in rejecting both attempts, affirmed that there are two related tests that any aid program in this area must pass: (1) the traditional secular purpose plus neutral effect standard first enunciated in Allen v. Board of Education, ${ }^{7}$ plus (2) the more recent "no excessive entanglement" standard first mentioned last year in Walz v. Tax Commission. ${ }^{8}$ The majority of the Court in Lemon, affirming what may be a legal cul-de-sac, found that the very attempts made by Pennsylvania and Rhode Island to separate secular from sectarian costs had excessively entangled them in the affairs of the church-related schools in violation of the Walz standard.

This fall the Court affirmed without opinion a lower court decision holding unconstitutional an Ohio program which would have reimbursed parents for up to $\$ 102$ of the tuition spent for each child in a nonpublic school. ${ }^{9}$ The lower court in Wolman v. Essex ${ }^{10}$ emphasized that the grants went only to nonpublic schools and that the schools were predominately of one religious group. ${ }^{11}$ This may indicate some willingness to distinguish aid proposals which involve all students and which provide enough aid per student that church-related schools need not be the primary beneficiaries. On the other hand, the lower court asserted that the principle of the First Amendment is to prohibit the state from providing any funds which directly support or sponsor any church-related institution, adding that 
this constitutional policy does not turn on the amount of aid a statute provides in any particular school year. ${ }^{12}$

A recent decision by a federal court in New York introduces another possible vehicle for effectively aiding only churchrelated schools. Committee for Public Education and Religious Liberty v. Nyquest ${ }^{\mathbf{1 3}}$ upheld New York state tax credits for a portion of the nonpublic school tuition paid on up to three children per family, despite a dissent arguing there is no difference between a parent's receiving a $\$ 50$ reimbursement for tuition paid to a parochial school and his receiving a $\$ 50$ benefit because he sends his child to a parochial school. ${ }^{14}$ One difference is that poor parents may not pay enough in taxes to receive any benefit. Tax credits may thus be even more detrimental to the education of most poor children than no benefits at all.

A critical factor in the future of nonpublic schools, therefore, will be whether the Supreme Court buys the "taxcredit-is-not-a-grant" distinction. If it does, church-related schools may be saved and even encouraged - but probably no others.

One hopeful sign for alternative school supporters is the interest that has been shown in trying an education voucher system. The Office of Economic Opportunity (OEO) has announced its willingness to help finance voucher demonstrations in which elementary school children would have their education financed for five or six years by allocating public education monies to parents in the form of vouchers or grants which could be redeemed at approved schools of their choice. ${ }^{15}$ The presumption is that schools would become more responsive to parents' interests in order to retain their students and budgets. The expected shift in orientation from a supplyto a demand-centered school system should facilitate the development of alternative schools both inside and outside the public system.

Currently Alum Rock, an elementary school district in San Jose, California, has begun an actual test of the voucher concept. Its test is limited to public schools this first year because the legislature failed to authorize the participation of any 
nonpublic schools in the test. Nonetheless, we will for the first time have a chance to see how parents in a community respond to the possibility of choosing among different schools for their children.

While most national education groups are on record as opposing even a test of vouchers, some have indicated support. ${ }^{16}$ Congress has resisted vigorous lobbying efforts to stop the OEO demonstrations. Connecticut, moreover, has passed legislation authorizing a full test at the option of one of its local school boards, ${ }^{17}$ and cities in New York, Ohio, and Wisconsin have expressed strong interest in hosting additional demonstrations.

Significantly, increasing numbers of educators have argued that they do not need vouchers in their communities because they are introducing choice within their school systems. It remains to be seen whether the choices offered will reflect the wishes of parents (even if they constitute only a minority by race, income, or educational taste in the community) or only those of the public school administrators. But the willingness even to speak in favor of parental choice represents a significant change.

\section{The Common School Tradition}

A major obstacle still confronting the alternative movement is our uniform common school tradition. From the earliest recorded school law (1647 in Massachusetts) designed to outmaneuver Satan's efforts to keep men from knowledge of the true Scriptures ${ }^{18}$ states have first offered and later forced schooling on ever larger numbers of individuals for ever longer periods.

Initially this effort was focused on poor children. In 1787 Benjamin Rush proposed a plan for a system of free schools for the poor children of Philadelphia. By 1804, Washington, D.C., had established such a school system for its poor children with Thomas Jefferson as its first school board president.

For children who were not poor, the primary responsibility remained for a time with their parents. As late as 1827 Kent 
observed: "During the minority of the child ... the parent is absolutely bound to provide reasonably for his maintenance and education; and he may be sued for necessaries furnished, and schooling given to a child, under just and reasonable circumstance." This obligation was not without its rewards: "In consequence of obligation of the father to provide for the maintenance, and, in some qualified degree, for the education of his infant children, he is entitled to the custody of their persons, and to the value of their labor and services." 19

But the common school doctrine soon spread to include schools for all children, not just the poor. The first publicly funded high school was established in 1821 . By 1890 about 7 percent of 14-17-year-olds were enrolled, and by 1930, 51 percent of this age group were in high school. ${ }^{20}$

By the 1880s the rationale for providing education focused less on moral or spiritual fulfillment and more on maintaining the social order:

The accumulation of riches in this country, brought about by the rapidity of industrial and commercial movements, tends to devote the sweat and lives of many to the few. If the elevation of the masses does not keep pace with this materialistic progress, misery and demoralization will increase in proportion to the augmentation of production. Communism and socialism will then claim to be heard. ... Nothing less than the State can check the prevalence of the revolutionary ideas and the assailment of social and proprietary rights.... Shall she establish a network of police force? This is the weakest and most unworthy of all remedies.... The first step of the State should be to get possession of the minds of men; get control of their ideas. ... This can be accomplished by a system of uniform, well-organized and liberally supported public schools. ... The power of education, rightly conducted, is almost omnipotent. It will make useful and peaceable citizens out of ninety percent of the worst children who fall under its influence. ${ }^{21}$

It was also at this point that the shift from voluntary to compulsory schooling took place, encouraged by a desire to Americanize the flood of immigrants: "It is largely through immigration that the number of ignorant, vagrant, and criminal youth has recently multiplied to an extent truly alarming in some of 
our cities. Their depravity is sometimes defiant and their resistance to moral suasion is obstinate. When personal effort and persuasion and organized benevolence have utterly failed, let the law take them in hand, first to the public school, and if there incorrigibly, then to the Reform School."22

Initially, the compulsory education laws allowed parents a range of choice in schooling. The 1874 New York law, for example, specified that children aged 8-14 could attend some public or private school for at least fourteen weeks a year, or be instructed at home for the same period in spelling, reading, writing, English grammar, geography, and arithmetic. ${ }^{23}$ By 1909, however, the state required regular attendance of children aged 7-16 at a public school conducted in English, or equivalent instruction by a competent teacher for the same number of hours. ${ }^{24}$

Today the common school doctrine has spread to the point where 90 percent of all students finish at least one year of high school and 80 percent graduate. ${ }^{25}$ It is a system in which control of the schools is concentrated in the hands of ever fewer educators and school boards. The number of school districts declined from 127,531 in 1930 to less than 20,440 in $1968 .{ }^{26}$ Even at that number, the supposed diversity of the systems is more illusory than real, especially in large cities. If someone were placed blindfolded in an elementary school classroom in New York, Chicago, or San Francisco, it is unlikely that he could tell one from another.

\section{Equal Opportunity Issues}

In addition to facing the steady trend toward uniform common schools, supporters of alternative schools must confront the need to promote equality of educational opportunity endorsed by the judiciary in Brown v. Board of Education. ${ }^{27}$ Unfortunately, the Brown decision has been translated by some into a justification for maintaining the present public system. Racial integration is easier to administer, so the argument goes, in a centralized system in which all schools are alike. The right proportion of each racial group can simply be bussed to every school. 
There are several reasons to question this view. There is first the issue of whether integration will be judicially required in all public school systems to the same extent that it has been in the South and isolated northern cities. If it is not, allowing parents to choose voluntarily among different types of schools may be the most important step toward more integration in schools. Certainly if a community or nation wants to integrate, a diversified school system need not be a hurdle. Schools could be required to meet a particular level of racial balance as a condition of receiving public funds.

Moveover, the judiciary has made it clear that publicly funded schools must desegregate. ${ }^{28}$ Providing funds to new and existing alternative schools could increase the overall level of racial integration in schools ${ }^{29}$ and provide better educational opportunities for more minority students.

Indeed, the constitutional line against racial discrimination in education is so firm that the judiciary recently withdrew the tax-exempt status of private schools which discriminate in admissions. ${ }^{30}$ The Court dismissed arguments that such action would conflict with contitutionally protected rights of association: "There is a compelling as well as a reasonable government interest in the interdiction of racial discrimination which stands on highest constitutional ground." 31 The Court refused to rely on statements by the Internal Revenue Service that it would enforce such a policy voluntarily. It also made clear that its ruling applies to any private school practicing racial discrimination and not just to the specific Mississippi schools mentioned in the case.

Three months later a Wisconsin federal district court followed suit and barred preferential state tax treatment, not just to schools but to any charitable organizations which discriminate in membership on the basis of race. ${ }^{32}$

Both these cases are important, not only for the firm stand they take with respect to racial discrimination but because they ease the way to a time when government focuses more on the relations between individuals and private organizations and less on operating services directly.

Thus, more diversity in schooling is possible without threat- 
ening equality of access. Increasing diversity may even be a better strategy for improving educational opportunities than simply fighting about equal access to the present public schools. Coleman has demonstrated that current public schools do little if anything to help poor or black children to learn as much as their middle-class white counterparts. ${ }^{33}$ More recently, Christopher Jenks has argued that even if school achievements were equalized, there is little reason to believe income or status inequalities would be offset by present public schools. ${ }^{34}$ These gloomy conclusions do not bar the possibility that different schools might make a significant difference, at least in noncognitive skills, even if reading and math scores change little.

Resolution of the problem of preventing racial discrimination leaves yet another major obstacle for alternative school supporters. The fight for more diversity, or, as some have phrased it, for family choice in education, ${ }^{35}$ is after all not a fight between families and some abstract entity. Rather it is a fight between a few families and the majority of their community. Sometimes it is a racial minority or an income minority; often, though, it is a minority by virtue of taste. Many poor families approve of their present public school for, rightly or wrongly, they consider it the best way to get their children into the mainstream of American economic life, while there are middle-income families who seek alternative schools which can provide less competition or regimentation. Traditional notions of who are minorities do not always hold.

The tension between minority tastes and the majority sometimes manifests itself as a plea for following "professional judgment." Many parents contend that some other parents would not make use of the opportunity to choose schools even if it were available, and therefore poor children would be worse off than under the present system of geographic assignment by the state. A slight variation of this position is the statement that professional educators know more than parents about what is a good education. This is a view some professionals no doubt encourage to strengthen the need for their services. 
Yet even if professionals could agree on what constitutes a good school or education, professionals do not assess each child: the process would be too unwieldy to administrate. Instead, the state matches students and schools for the most part on the basis of residence.

Concern for the impact of choice on uninformed parents is well founded, but the concern might better be directed to providing parents with sufficient information to make wise choices. The strength of the resistance even to this effort is hard to explain. Possibly some of the resistance to allowing parents to make educational choices - even narrow ones limited to state-approved alternatives - reflects a sex bias. Women, at least traditionally, as closest to Johnny's experience in school. Family choice in education would be primarily the woman's choice. While it is true that most elementary and many secondary school teachers are women, educational administrators, boards of education, and state legislators are overwhelmingly men. To the extent that legislative and board policies and admissions decisions constrain the influence of a given teacher, favoring professional choice over family choice in education is likely to maintain the power of male over female in making educational choices for children.

Alternative schools may be a reform favored only by minority interests. Legislatures, therefore, are likely never to support alternative schools. As with legislative reapportionment, the counter-majoritarian power of the courts may be needed.

\section{Prospects for Judicial Support}

Prospects for support of alternative schools are not necessarily any better in the courts. All of the arguments against forays into a political thicket which were raised against reapportionment are likely to be used again. The Nixon Court is not likely to rush into such activism. There is, however, some precedent that can be mustered in favor of judicial protection of minority interests in education.

Initially most courts did little to counter the common school movement. They upheld legislation to levy taxes to pay for 
schooling ${ }^{36}$ and confirmed the right of states to prosecute parents who did not send their children to school. ${ }^{37}$ Even then, some state courts did protect the right of parents to pick and choose among the curriculum offerings of the schools they were being forced to use. ${ }^{38}$

The public school movement proceeded successfully without judicial intervention until the early twenties. Then in several landmark cases the Supreme Court stepped in to offer some protection to minority interests in education.

In Meyer v. Nebraska the Court held unconstitutional a statute which prohibited teaching modern foreign languages to any student who had not yet passed the eighth grade. The Court observed that three rights were at issue: "the occupation rights of modern language teachers," "the opportunities of pupils to acquire knowledge," and "the power of parents to control the education of their own children." 39 But the case before the Court really raised only the first issue, because it involved an appeal of the conviction of a young teacher who had taught German to students in a Lutheran elementary school. ${ }^{40}$ The precedential value of the decision is, therefore, somewhat weak, although replete with verbal kudos for minority tastes in education.

In Pierce v. Society of Sisters, ${ }^{41}$ the Court overturned an Oregon statute (inspired by the Klu Klux Klan) which would have required all students to attend public schools. Although the plaintiffs this time were private schools, the Court again raised the rights of parents and children in its opinion which contains the modern nonpublic schools' Magna Charta: "The fundamental theory of liberty upon which all governments in this Union repose excludes any general power of the State to standardize its children by forcing them to accept instruction from public teachers only." 42

When Pierce was decided, no one focused much on the fact that the "right" there established was a hollow victory for anyone unable to afford private schooling. But since Pierce, certain rights have been singled out by the Court as so fundamental that they must be made equally available to the poor and the rich. These include certain criminal procedure rights, ${ }^{43}$ voting 
rights, ${ }^{44}$ and the right to travel. ${ }^{45}$ Many have argued that educational rights are certainly as fundamental as these others-since the significance of the franchise, for example, may depend as much, if not more, on education as on procedural niceties.

In the past few months an increasing number of courts have accepted the proposition that education is such a fundamental right. ${ }^{46}$ It is, therefore, now possible that for the first time courts will be willing to combine the Pierce doctrine with this expanded concern for protecting the educational rights of the poor in a fashion that provides judicial support for alternative schools. The judiciary might, for example, be moved to empower the poor to have their share of public education resources devoted to schools of their choice in a quasi voucher program. ${ }^{47}$

The hypothetical suit outlined above highlights some of the difficulties of using the equal protection clause to protect the rights of the poor. The judiciary might simply order private schools to admit students without regard to family income, just as they are now moving to require private schools to admit students without regard to race ${ }^{48}$ But the result would be to bankrupt most of the private schools. In other words, protecting the rights of the poor, in education as elsewhere, requires state financial support as well as criminal sanctions if it is to work. But ordering legislatures to appropriate money potentially infringes on the traditional separation of powers so much that the judiciary has understandably been willing to do so only in limited areas.

There may be more justification for the courts to order legislatures to appropriate funds for education than in some of the other areas where action has already been taken. Ordering the states to provide lawyers to poor criminal defendants, for example, entailed a new expense. An order requiring the funding of qualified alternative schools, by contrast, would involve simply a reallocation of funds which must otherwise be spent for the same students in the public system. Reallocation is not such a big step as ordering new expenditures outright, particularly in view of the recently demonstrated judicial will- 
ingness to reallocate public education funds among public schools within school districts, ${ }^{49}$ and among public districts themselves. ${ }^{50}$

The courts might be reluctant however to provide control of funds to individual families without any restrictions on how they are used. Families might simply keep the money and pretend to educate the children at home, or spend it in institutions which taught little. A more acceptable request in the eyes of the judiciary, therefore, might be a joint request for funding from parents and from the specific alternative school of their choice. The school would have to demonstrate that it met all state and local certification requirements before it could become eligible for funding. An advantage of this approach is that it would create some private regulation. Several families would have to agree on the worth of a school before a funding request could be made. The process would guard against the unacceptable idiosyncracies of an isolated family where the parents did not really have the best interests of their children at heart.

Countless hurdles to such a suit come immediately to mind. Just how would a school prove it was "public" enough to be entitled to public funding? Proof that religion was not taught would probably be essential. ${ }^{51}$ A policy of nondiscriminatory admissions would need to be shown. Compliance with state and local education standards would have to be demonstrated. ${ }^{52}$ Placing the total burden on the school might make successful proof impossible. Ideally, it should be sufficient to show prima facie compliance with existing standards. The burden would then be on the state to show why the school desired by this group of parents was not an acceptable recipient of public funds. ${ }^{53}$

The one recent case to challenge the right of the state to compel attendance at state-approved schools does not offer much encouragement to alternative school enthusiasts. In Wisconsin v. Yoder ${ }^{54}$ the Supreme Court was asked to approve a state court decision exempting Amish students from school after the eighth grade. The Court upheld the decision, but it seemed more moved by the fact that the Amish are "very 
law-abiding members of society [who] reject public welfare in any of its usual modern forms" 55 than by any concern for educational diversity. As Chief Justice Burger observed, "[It] cannot be over-emphasized that we are not dealing with a way of life and a mode of education by a group claiming to have recently discovered some 'progressive' or more enlightened process for rearing children for modern life." 56

Since neither legislative nor judicial support for funding alternative schools is likely in the immediate future, the best hope for alternative school supporters appears to be negotiating with school boards either to give some public schools enough autonomy to remodel themselves, or to allow a few private alternative schools in the public system whether by fiat or contract. Subcontracts were let to private interests in specific subjects during the abortive performance contracting experiments sponsored by the OEO. It may similarly be possible to contract out an entire school. The danger with such incremental change, as usual, is that it may be co-opted by the process to the point that it is no change at all.

Plato wanted guardians to rear children. We have learned that some parents are not fit for the job, but having the state rear all children hardly seems a better alternative. Our country needs an intermediate institution that is more personalized than a state system, yet more egalitarian than the old family centered system which failed to protect some children from their parents' negligence. Schools can perhaps be that intermediate "community," but only if individual families can share with the state the responsibility of shaping them.

1. See the 1971 New Schools Directory Project, sponsored by HEW and summarized by Allen Graubard in "The Free School Movement," Harvard Educational Review 42 (1972): 351.

2. In 1969 approximately five out of every six students in nonpublic elementary schools were in Catholic schools (U.S., Department of Commerce, Bureau of the Census, Statistical Abstract of the United States [Washington, D.C.: Government Printing Office, 1971], tables 175 and 181, pp. 116- 19 [hereafter cited as 1971 Statistical Abstract]).

3. The semantic contortions demonstrate the inadequacy of current definitions of public or private schools, which focus more on who runs schools than on how they are run. Some schools run by the state, for 
example, do not have "public" admissions policies. Instead they limit admissions to children of families of upper-income levels either directly (by tuition charges in the case of some state colleges) or indirectly (by requiring the families to be able to afford residence in a particular neighborhood). Conversely, some schools run by private interests are not only free to all who wish to come but often are more candid about what the school is like, its teachers, and its facilities than many conventional public schools. As long as schools have open admissions and disclosure policies (and meet all state and local educational requirements) the differences seem minimal. Yet some receive public funds and others do not.

4. See, e.g., the statement of Harvey Scribner, chancellor of the New York City Schools: "Instead of a voucher system, I would argue at this time for the creation of new educational options and alternatives within the public sector of education so that parents would not be forced to leave the public schools in search of alternatives" (New York Times, May 5, 1971).

5. See, e.g., the Constitution of the Commonwealth of Massachusetts.

6. 91 Sup. Ct. 2105 (1971).

7. 392 U.S. 236 (1968).

8. 397 U.S. $664(1970)$.

9. 41 U.S.L.W. 3167 (Sup. Ct. 10/10/72).

10. 40 U.S.L.W. 2724 (U.S.D.C.S.Ohio).

11. Opinion at 21.

12. Opinion at 32 .

13. 41 U.S.L.W. $2182(10 / 2 / 72)$.

14. 41 U.S.L.W. 2183.

15. See "A Proposed Experiment in Education Vouchers," OEO pamphlet 3400-1 (January 1971).

16. See, e.g., Resolution of the Education Commission of the States, adopted July 9, 1971: "Be it resolved that the Education Commission of the States urges local school systems, assisted by state and federal resources, to experiment with demonstration projects for such educational innovations as performance contracting and educational vouchers, provided that such projects contain appropriate involvement of parents and professional educators in their development and provide safeguards against racial and economic discrimination and provisions for evaluation."

17. Connecticut Public Act no. 122 (1972).

18. Mass. Records 2:203, quoted in Children and Youth in America, ed R. Bremner (Cambridge, Mass.: Harvard University Press, 1970), 1:80-81.

19. J. Kent, Commentaries on American Law (New York: Plenum Publishing Corp., 1971), 189-205.

20. 1971 Statistical Abstract, table 165, p. 110.

21. J. E. Seamen, "High Schools and the State,"Journal of Proceedings (1886), pp. 155-75 (addresses of the National Education Association, New York, 1885).

22. B. G. Northrop, "Report of the Secretary of the Board of Education of the State of Connecticut, 1872," quoted in Children and Youth in America, ed. R. Bremner (Cambridge, Mass.: Harvard University Press, 1971), 2:1420-22.

23. N.Y., Congress, Laws of the State of New York, 97th Cong., 1874, ch. 421, pp. 523-35. 


\section{Alternative Schools}

24. N.Y., Congress, Laws of the State of New York, 132d Cong., 1909, ch. 409 J, pp. 880-88.

25. 1971 Statistical Abstract,pp. 124-35.

26. U.S., Department of Health, Education and Welfare, Digest of Educational Statistics, vol. 42 (1969).

27. 347 U.S. 483 (1954).

28. See Coffey v. State Education Finance Commission, 296 F. Supp. 1389 (S.D. Miss. 1969); Griffin v. State Board of Education, 296 F. Supp. 1178 (E.D. Va. 1969); Poindexter v. Louisiana Financial Assistance Commission, 296 F. Supp. 686 (E.D. La.), affd per curiam sub nom Louisiana Education Commission for Needy Children v. Poindexter, 393 U.S. 17 (1968); Brown v. South Carolina State Board of Education, 296 F. Supp. 199 (D.S.C.), aff'd per curiam 393 U.S. 222 (1968).

29. The United States Commission on Civil Rights has concluded that "private and parochial school enrollment, which is overwhelmingly white, also is a significant factor in the increasing separation of white and Negro school children" (Racial Isolation in the Public Schools [Washington, D.C., Government Printing Office, 1967], p. 31). The Commission found that nearly 40 percent of the white elementary school students in fifteen large metropolitan areas attended nonpublic schools in 1960; almost all of the schools were white (ibid., p. 39).

30. Green v. Connolly, 330 F. Supp. 1150 (1971), affd sub nom Green v. Coit, 40 U.S.L.W. 3286 (Sup. Ct. 12/21/71).

31. Ibid. at 1167 .

32. Pitts v. Wisconsin Department of Revenue, 40 U.S.L.W. 2245 (1971).

33. J. Coleman et al., Equality of Educational Opportunity (Washington, D.C.: Government Printing Office, 1966).

34. C. Jencks et al., Inequality: A Reassessment of the Effect of Family and Schooling in America (New York: Basic Books, 1972).

35. John Coon, "Recreating the Family's Role in Education," Inequality in Education (Cambridge, Mass.: Harvard Center for Law and Education, 1970).

36. See City of Louisville v. Commonwealth, 134 Ky. 488, 121 S.W. 411 (1909); Stuart v. School District No. 1 of Kalamazoo, 30 Mich. 69 (1874).

37. See State v. Bailey, 157 Ind. 59, 61 N.E. 730 (1901).

38. See School Board District No. 18 v. Thompson, 24 Okla. 1, 3, 103 Pac. 578, 579 (1909): "In our mind the right of the board of education to prescribe the course of study and designate the text books to be used does not carry with it the absolute power to require pupils to study all of the branches prescribed in the course in opposition to the parents' reasonable wishes in relation to some of them.... And how it will result disastrously to the proper discipline, efficiency and wellbeing of the common schools, to concede this paramount right to the parents ... is a proposition we cannot understand."

39. 262 U.S. 390 (1923).

40. But see Griswold v. Connecticut, 381 U.S. 479, 482 (1965), where the Court states, "By Pierce v. Society of Sisters ... the right to educate one's

\section{School Review}


children as one chooses is made applicable to the States by the force of the First and Fourteenth Amendments."

41. 268 U.S. 510,535 (1935).

42. Ibid., p. 535; see also Farrington v. Tokushige, 273 U.S. 284 (1926), in which the Court struck down a Hawaii statute that stringently regulated Japanese foreign language schools on the grounds that it deprived parents of a fair opportunity to procure for their children instruction which they thought important and which the Court did not consider harmful.

43. Douglas v. California, 372 U.S. 353 (1963); Griffin v. Illinois, 351 U.S. 12 (1956).

44. Harper v. Virginia Board of Elections, 383 U.S. 663 (1966).

45. Shapiro v. Thompson, 394 U.S. 618 (1969).

46. Rodriguez v. San Antonio Independent School District, 40 U.S.L.W. 2398 (D.C. Tex. 12/13/71); Van Dusartz v. Hatfield, 40 U.S.L.W. 2228 (U.S.D.C. 1971); Serrano v. Priest, 40 U.S.L.W. (Cal. Sup. Ct. 1971).

47. Cf. Shelton v. Tucker, 264 U.S. 479, 488 (1960): "Even though the governmental purpose be legitimate and substantial, that purpose cannot be pursued by means that broadly stifle fundamental personal liberties when that breadth of legislation must be reviewed in light of less drastic means for achieving the same basic purpose."

48. See p. 184.

49. See Hobson v. Hansen, 269 F. Supp. 401 (D.D.C. 1967), affd sub nom Smuck v. Hobson, 408 F.2d 175 (D.C. Cir. 1969).

50. See cases cited n. 46 above.

51. Cf. Brusca v. Missouri, 332 F. Supp. 275 (U.S.D.C. E.Mo.) judg. aff'd 40 U.S.L.W. 3502 (4/18/72).

52. The power of the state to regulate all schools, public and private, is already clear (see Allen v. Board of Education, 392 U.S. 236 [1968]).

53. For an elaboration of judicial theories for obtaining public funds for nonpublic schools, see S. Arons, J. Kobrick, and J. Areen, "Public Schools and the First Amendment: A Proposal for Structural Reform" (unpublished paper available from the Center for the Study of Public Policy, Cambridge, Massachusetts, 1971).

54. 40 U.S.L.W. $4476(5 / 15 / 72)$.

55. Ibid., p. 4481.

56. Ibid., p. 4485. 